\title{
Seismology at Kew Observatory
}

T HE most complete seismological equipment in the British Isles is at Kew Observatory, and thanks largely to the enterprise of its superintendent, Dr. F. J. W. Whipple, the performance of this has recently been vastly improved. Dr. A. W. Lee, the seismologist at Kew, has now written an account of the new installation (Meteorological Office, Geophysical Memoirs No. 78, sixth number, 9. London : H.M. Stationery Office, 1939. 2s.).

The three Galitzin seismographs, originally presented to Eskdalemuir Observatory by the late Sir Arthur Schuster, were, after transference to Kew, placed on a massive concrete pillar in the basement of the main building but isolated from it. These instruments were greatly influenced by the wind, and it was found by experiment with a Milne-Shaw instrument borrowed from the Science Museum, that the effect was not due to direct draughts on the instruments but to the rocking of the whole building and the surrounding subsoil by the wind; hence the entirely new building to house the seismographs, which was ready for occupation early in 1937. The two Wood-Anderson seismographs constructed at Kew (1933 and 1935) were transferred in February, the Galitzin horizontal pendulums in April, and the vertical Galitzin in September 1937.

The new building, which has two rooms at the same level, is situated about $100 \mathrm{yd}$. south-south-west of the main observatory building, and has its floor
$5 \mathrm{ft}$. below the level of the surrounding paddock. The ceiling is covered by soil and turfed, the level of the turf being about $5 \mathrm{ft}$. above the surroundings. The whole is made to withstand the weather, and the temperature of the ventilated rooms is thermostatically controlled.

The south room, $20 \mathrm{ft}$. by $15 \mathrm{ft}$., contains the seismographs on concrete pillars built directly on the floor, and the north room, $10 \mathrm{ft}$. by $15 \mathrm{ft}$., contains the galvanometers and recording drum for the Galitzin pendulums on slate slabs cemented to concrete pillars. The timing is by a Hope Jones synchronome (No. 1901) standard clock which is arranged to give time breaks of 2 sec. at the minute and 4 sec. at the hour accurate to within a few tenths of a second, on recording paper fixed to an electrically driven drum. The rate is $15 \mathrm{~mm}$. per minute. The small Wood-Anderson instruments have a static magnification of about $700: 1$ and the instruments at Kew are adjusted to have a free period of $2 \cdot 5$ sec. with a damping ratio of approximately $20: \mathrm{I}$. Both north-south and east-west components are made to register on the same drum in a similar manner to the three Galitzin instruments.

It is confidently expected that in addition to welcome minor improvements, the changes will have obtained for the Kew seismograms that freedom from wind effect and more uniform drum rate than with the separate clockwork drives which was so much desired.

\section{The First Imperial Veterinary Conference}

$\mathrm{T}$ HE Imperial Agricultural Research Conference which was held in London in 1927 recommended that certain specialized imperial agricultural bureaux should be established, and as a result ten bureaux are now in operation. Two important events have since taken place. Following the Ottawa Conference of 1932, the Imperial Committee on Economic Consultation and Co-operation, in 1933, examined and reported on inter alia the work and functions of these bureaux; and in 1936 the British Commonwealth Scientific Conference met.

The First Imperial Veterinary Conference is one of the many important developments of the Imperial Agricultural Research Conference of 1927. It was held in London in August last and was attended by delegates from the United Kingdom, from each of the Dominions, and from Colonial Territories*.

The Conference was opened by Mr. F. L. McDougall. a former chairman of the Council of the Imperial Agricultural Bureau, who pointed out the economic importance of the livestock industry to the several territories of the British Empire, and directed atten. tion to the results that have been achieved in the control of animal disease. The sessions of the Conference were devoted to consideration of the working of the Imperial Bureau of Animal Health and to discussion on certain disease subjects of outstanding interest. The deputy director read a report on the work of the Bureau: At the present stage of its development, the maintenance of the indexing and abstracting services is the main activity. Index Veterianarius, issued half-yearly, is a classified subject and author catalogue dealing with about 10,000 references per annum. The Veterinary Bulletin, issued monthly, is devoted to abstracts, of which about 3,500 appear annually. The development of a review service is imminent. A special committee was appointed by the Conference to report on the Bureau.

At the sessions devoted to disease subjects, "Footand-Mouth Disease", "Gaseous Lymphadenitis of Sheep", "Virus Diseases of Animals", "Laryngotracheitis", "Infectious Bronchitis and Corzya of Poultry", "Blowflies of Sheep", "Fowl Paralysis", "Bovine Mastitis", "Johne's Disease" and "Chronic Bovine Hæmaturia" were discussed.

Resolutions were passed emphasizing the importance of the Imperial Bureau of Animal Health and recommending certain developments in its activities, on the importance of work concerning a reliable diagnostic agent for Johne's disease, and on the danger of using certain prophylactic measures for the control of foot-and-mouth disease and some other virus diseases.

- Report of the First Imperial Veterinary Conference, 15th-18th August 1938. Pp. 97. (Weybridge : Imperial Bureau of Animal Health, 1938.) 58 . 